\title{
Wielkopolskie organizacje kobiece u schyłku XIX w. a uczestnictwo Polek w przestrzeni społecznej II Rzeczypospolitej Polskiej
}

Wyobrażając sobie życie kobiety ponad sto lat temu, zazwyczaj ograniczamy je do sfery prywatnej, rodziny i wychowywania dzieci. Zaraz jednak, sprawiedliwie dla wysiłków Polek tamtego okresu, przypominamy sobie o działalności patriotycznej. Tak z przestrzeni prywatnej wkraczamy w publiczną, społeczną, a zatem służącą nie tylko członkom rodziny. Przestrzenią społeczną wypada nam określić wszystkie podejmowane przez kobiety działania, których rezultat wpływał na kształt społeczeństwa. Zawężając nieco problematykę do Wielkopolski, należy pamiętać o roli politycznej i obliczu ideowym regionu w czasie jego przynależności do zaboru pruskiego i w okresie II Rzeczypospolitej. Celem było zatem pokazanie skali przemian zachodzących w społeczeństwie na terenie Wielkopolski. Przemian, których symptomy zauważyć możemy pod koniec XIX w., a których rezultaty ujawniły się w świadomej działalności Polek dwudziestolecia międzywojennego. Poświęcano dotąd uwagę aktywności kobiet wielkopolskich, publikując $w$ pracach zbiorowych teksty dotyczące ich obecności $w$ różnych sferach życia ${ }^{1}$.

Omawiając kwestie organizacji kobiecych na terenie Wielkopolski, należy podkreślić niezwykle trudne warunki funkcjonowania Polek w państwie

${ }^{1}$ Zob.: Działaczki społeczne, feministki, obywatelki. Samoorganizowanie się kobiet polskich po 1918 r. (na tle porównawczym), t. 2, pod red. A. Janiak-Jasińskiej, K. Sierakowskiej, A. Szwarca, Warszawa 2009; Humanistyka i płeć. Publiczna przestrzeń kobiet. Obrazy dawne i nowe, t. 3, pod red. W. Hellera, E. Pakszys, Poznań 1999; Kobieta i świat polityki: Polska na tle porównawczym w XIX i na początku XX wieku. Zbiór studiów, pod red. A. Szwarca, A. Żarnowskiej, Warszawa 1994; Kobiety w Polsce międzywojennej. Równe prawa i nierówne szanse, pod red. A. Szwarca, A. Żarnowskiej, Warszawa 2000. 
niemieckim². Główną determinantą, która powodowała, że określenie ich rzeczywistego zaangażowania w życie społeczne nie należało do zadań łatwych, było prawo państwa niemieckiego, w myśl którego kobiety nie mogły zakładać stowarzyszeń, a rzadko przyjmowano je w struktury męskich organizacji. Koniec XIX w. przyniósł przełom w zakresie emancypacji kobiet. Niemieckie emancypantki odniosły połowiczne zwycięstwo, czego dowodami były nowy kodeks cywilny i kodeks handlowy, a wraz z ich wprowadzeniem kobiety stały się podmiotami prawa. Obejmowało je ono tylko w sferze zarobkowania i spraw rodzinnych, pozwalając im współdecydować o losie rodziny, ale jak wspominał Kazimierz Żuromski: „[...] Przy zaprowadzeniu nowego kodeksu cywilnego uwzględniono jedynie te żądania kobiet, które odnosiły się do stosunków życia rodzinnego i samodzielnej ich zarobkowości. Natomiast kodyfikacja prawa publicznego żadnej nie stworzyła korzystnej dla kobiet reformy. Stanowisko kobiety jako obywatelki pozostało to same co dawniej, czyli że obowiązki jej obywatelskie są małe, za to prawa i przywileje w życiu publicznym jeszcze mniejsze $[\ldots]^{\prime \prime}$.

Pośród licznych spraw, na które wpływu nie miały, znajdowało się także zakładanie organizacji politycznych i uczestnictwo $\mathrm{w}$ ich działalności. Prawodawca nie widział potrzeby nadawania w tym zakresie praw kobietom, społeczeństwo jednak, na przekór obowiązującym zasadom forsowało własne rozwiązania ${ }^{4}$. Szczególnie Polacy dążyli do tego, aby umożliwić kobietom działalność w organizacjach narodowych. Początkowo na czele towarzystw kobiecych jako opiekunowie lub współzałożyciele stawali mężczyźni. Tak było m.in. w przypadku organizacji Warta ${ }^{5}$ oraz Stowarzyszenia Personału Żeńskiego w Handlu i Przemyśle ${ }^{6}$. Zachęcano kobiety do pracy społecznej, która pod koniec XIX stulecia dotyczyła ochrony tożsamości narodowej, interesów mniejszości polskiej w państwie niemieckim, a w mniejszym stopniu odwoływała się do sporów emancypacyjnych wokół zadań kobiety w nadchodzącym stuleciu, czy przejmowania obowiązków w nowych zawodach.

Specyficznie rozumiano również zakres „przestrzeni społecznej”, ograniczając ją do sfery życia rodzinnego i zawodowego, pomijając wpływ kobiet na

${ }^{2}$ M. Abram, Aktywizacja polityczna kobiet polskich na przełomie XIX i XX wieku, w: Humanistyka i płeć. Publiczna przestrzeń kobiet, s. 81-82; S. Karwowski, Historia Wielkiego Księstwa Poznańskiego, t. 3, 1890-1914, Poznań 1931, s. 236.

${ }^{3}$ K. Żuromski, Prawo kobiety w Niemczech, Poznań 1904, s. 130.

${ }^{4}$ M. Pietrzak, Sytuacja prawna kobiet w II Rzeczypospolitej, w: Kobiety w Polsce międzywojennej. Równe prawa i nierówne szanse, pod red. A. Szwarca, A. Żarnowskiej, Warszawa 2000, s. 28.

${ }^{5}$ Duchowym opiekunem, współorganizatorem i prawnym opiekunem Towarzystwa Warta był Bernard Chrzanowski, zob.: G. Łukomski, Bernard Chrzanowski (1861-1944). Biografia Polaka zachodniokresowego, Poznań-Opalenica 2005, s. 149-150.

${ }^{6}$ Pośród współzałożycieli Stowarzyszenia Personału Żeńskiego w Handlu i Przemyśle byli m.in.: Wiktor Gładysz, Kajetan Ignatowicz, Teofil Preiss, zob.: A. Koehlerówna, Zofia Tułodziecka. Pionierka ruchu zawodowego w Wielkopolsce. Życiorysy zastużonych kobiet, Kraków 1933, s. 7. 
życie polityczne, czy zupełnie nie biorąc pod uwagę możliwości ich uczestnictwa w czynnej walce o niepodległość. Wykluczano je zatem z obszarów, w których wykazywały aktywność. O ile na początku stulecia panie posiadające własne przekonania polityczne należały do rzadkości, o tyle na przełomie wieków brały czynny udział w życiu społecznym, posiadały swoje poglądy polityczne, czytywały prasę ogólnozaborową i były świadome odrębności narodowej, a także konieczności walki o niepodległość państwa. Walki rozumianej nie jako czyn zbrojny, lecz codzienna praca nad uświadomieniem tych kobiet, którym zagadnienia polityki, rozstrzygane w Berlinie, wydawały się zbyt odległe ${ }^{7}$.

Po wprowadzeniu wspomnianych już kodeksów w prawie niemieckim nie zachodziły zmiany korzystne dla kobiet aż do roku 1908, kiedy w życie weszła nowa ustawa o stowarzyszeniach. De facto ustawa ta nie była zadowalająca dla mniejszości narodowych, w tym i dla Polaków, wprowadzała bowiem zakaz organizowania spotkań, wieców, zebrań w języku narodowym, jeśli żaden z urzędników niemieckich w rejonie nie posługiwał się nim. Polki, które na co dzień były nauczycielkami języka polskiego, podtrzymywały tradycję narodową, odczuły nowe prawa jako kolejny środek godzący w polską rację stanu, słusznie komentując zapowiedzi Bernharda von Bülowa i jego stronników na łamach prasy ${ }^{8}$. Zauważyły jednak, że obok licznych komplikacji dla polskiego ruchu narodowego pojawiła się dla niego również szansa rozwoju. Wprowadzana ustawa o stowarzyszeniach otworzyła kobietom drogę do udziału w życiu publicznym, a zatem także Polki uzyskały prawo do zakładania towarzystw i zaangażowania się w już istniejących. Pozwolono na otwarty udział kobiet w obradach organizacji, na zabieranie głosu, wygłaszanie referatów. Wielkopolanki zachęcały do zakładania nowych towarzystw, do włączania w ich pracę robotnic fabrycznych, a także kobiet wiejskich. Z sukcesu emancypantek niemieckich (Polki w zaborze pruskim nie miały aspiracji do pełnienia funkcji publicznych $w$ takim stopniu jak Niemki) chciały uczynić oręż w walce o sprawę narodową, stąd też gorąco zachęcały do tworzenia kobiecych organizacji, do zaangażowania w życiu publicznym: „[...] wstępujmy do stowarzyszeń politycznych, do »Straży «, albo też zawiązujmy stowarzyszenia polityczne żeńskie osobne, gdziebyśmy naprzód nabyły tej elementarnej podstawy, ku zrozumieniu urządzeń państwa, miasta i gminy, w której żyjemy [...]" 9 .

\footnotetext{
${ }^{7}$ Obok nakłaniania mężczyzn do udziału w stowarzyszeniach i wyborach, panie na łamach czasopism kobiecych otwarcie wyrażały poglądy politycznie, trafnie oceniały politykę prowadzoną przez państwo niemieckie jako niebezpieczną dla polskiej tożsamości narodowej. Zob.: Zadanie Polki wobec dwóch nowych ustaw, „Dobra Gospodyni. Pismo tygodniowe ilustrowane dla Polek" nr 24 z 19 czerwca 1908 r., nr 25 z 20 czerwca 1908 r.

8 "Dobra Gospodyni", nr 25 z 26 czerwca 1908 r.

9 Tamże, nr 26 z 3 lipca 1908 r.
} 
Bardzo wolno, choć konsekwentnie, zmieniano przekonania o roli i miejscu kobiety w społeczeństwie. U schyłku XIX w. istniały towarzystwa kobiece, w których koncentrowano się na pracy charytatywnej, tworzono coraz więcej organizacji zrzeszających pracownice zawodów takich, jak: krawiectwo, modniarstwo, fryzjerstwo, księgowość itp. Najczęstszą formą udziału kobiet w życiu publicznym było organizowanie wieców. Podczas spotkań omawiano zarządzenia niemieckie godzące $w$ szkolnictwo prywatne, sprawy związane z wykształceniem kobiet oraz ich pracą zarobkową ${ }^{10}$. Stanowiły one również doskonały pretekst do podsumowania dotychczasowej działalności kobiet i wskazania jej nowych kierunków. Gromadziły one najprężniej działające panie, które nie wahały się wskazywać zarówno dobrych, jak i słabych stron współpracy wewnątrz towarzystw. Warto wspomnieć, że podczas krakowskiego zjazdu kobiet, 11-12 maja 1913 r., z ziem zaboru pruskiego goszczono Anielę Tułodziecką, czołową działaczkę, założycielkę m.in. Towarzystwa Przyjaciół Wzajemnego Pouczania i Opieki nad Dziećmi Warta, która w obszernym referacie przedstawiła stan relacji w zaborze, oddając nie tylko trudności, którym przeciwstawiały się członkinie, ale też wskazując wady w postępowaniu pań, niewystarczająco angażujących się w prace nad poprawą sytuacji Polaków.

Omawiając zadania realizowane $\mathrm{w}$ towarzystwach, wskazywała organizacje funkcjonujące od początku drugiej połowy XIX w., takie jak chociażby Towarzystwo Pomocy Naukowej dla Dziewcząt Polskich, ale znaczącą część wystąpienia skoncentrowała na sprawach bieżących i rozwoju instytucji zakładanych przez kobiety w ostatnim dziesięcioleciu XIX w. Jako założycielka Warty szczegółowo omówiła działalność towarzystwa, wskazując na naturalne, jej zdaniem, powołanie kobiety do opieki i wychowywania dzieci. Łącząc je z potrzebą ochrony narodowości panie zdecydowały założyć Wartę, która początkowo miała na celu prowadzenie zajęć z języka polskiego i historii, pomoc w odrabianiu lekcji, a z czasem poszerzyła swoją działalność. Kobiety zorganizowały bibliotekę, gromadziły i wypożyczały polskie książ$\mathrm{ki}$, a z czasem urządziły odczyty dotyczące wychowania i pielęgnacji dzieci ${ }^{11}$. Dzieci, oprócz nauki, jeździły na wycieczki, bawiły się razem, spędzały czas w polskim gronie. Po pierwszych, krytycznych wobec nowatorskiego pomysłu uwagach rodzice coraz chętniej powierzali "warciankom” swoje pociechy. W ciągu dwóch miesięcy od założenia organizacji zapisano do niej ponad tysiąc dzieci, które miały pobierać naukę, w regularnych zajęciach uczest-

${ }^{10}$ J. Sikorska-Kulesza, Trójzaborowe zjazdy kobiet na ziemiach polskich na przełomie XIX i XX wieku, w: Działaczki społeczne, feministki, obywatelki. Samoorganizowanie się kobiet do 1918 roku (na tle porównawczym), t. 1, pod red. A. Janiak-Jasińskiej, K. Sierakowskiej, A. Szwarca, Warszawa 2008, s. 85 .

${ }^{11}$ M. Abram, dz. cyt., s. 88-89. 
niczyło około czterystu dzieci ${ }^{12}$. Tak duże przedsięwzięcie zmusiło panie do ustalenia dokładnego harmonogramu zajęć, programu nauczania, a także znalezienia wychowawczyń, które gotowe były do podjęcia wyzwania. Nade wszystko wymagało ono całej rzeszy osób gotowych poświęcić czas i zaryzykować swoją wolność dla zachowania tradycji narodowej i przygotowania najmłodszego pokolenia do funkcjonowania w niepodległym państwie. Ten ostatni cel przyświecał wszystkim organizacjom kobiecym.

Pamiętać zatem należy o tym, że dawanie wykształcenia, podnoszenie własnych umiejętności i podejmowanie trudu związanego z nielegalną działalnością na rzecz polskości kształtowały ducha obywatelskości i rozbudzały w kobietach poczucie odpowiedzialności za Polskę. Jednocześnie znamienne było dla Wielkopolski i ziem zaboru pruskiego, że mimo chęci udziału w życiu społecznym, kobiety nie domagały się emancypacji, nie rościły sobie prawa do bycia traktowanymi w każdej dziedzinie życia na równi z mężczyznami. Mimo wysokiej aktywności kobiet, nie było nowych ochotniczek, a te, które się zgłaszały, posiadały dobre zamiary, lecz brakowało im kompetencji. Obok kłopotów kadrowych nieustannym problemem było prawo niemieckie, zabraniające nauki języka polskiego, podnoszące kary nie tylko dla rodziców, którzy posyłali swoje dzieci na tajne kursy, lecz i dla wychowawczyń, co - jak wspominała Tułodziecka - „zaowocowało” odejściem części nauczycielek ${ }^{13}$. Wielu inicjatyw podjętych przez kobiety nie udało się podtrzymać, jedną z nich było Przytulisko dla Dziatwy Szkolnej, otwarte w 1899 r., a zamknięte $\mathrm{w}$ niespełna trzy lata później. Podobnie było z prelekcjami dla matek, cieszyły się one dużą popularnością, ale dla niemieckiej administracji stanowiły zagrożenie. Odbywały się w języku polskim, dotyczyły szeroko pojętej pielęgnacji dzieci, w tym i rozwoju w duchu patriotycznym, a więc zostały poczytane za antyniemieckie i zakazane ${ }^{14}$. Stałym elementem działalności kobiet wielkopolskich były czytelnie ludowe, funkcjonujące nie tylko w Poznaniu, lecz i poza nim.

Interesującą inicjatywą, będącą zarazem świadectwem wyodrębnienia się nowej grupy w społeczeństwie, było Stowarzyszenie Personału Żeńskiego w Handlu i Przemyśle. Założone w 1903 r. zrzeszało kobiety pracujące m.in. w zawodach krawcowych, modniarek i fryzjerek. Obok walki o poprawę warunków pracy i wynagrodzenia pojawiły się również kursy przygotowujące do egzaminów w Izbie Rzemieślniczej ${ }^{15}$. Nauczano pisowni polskiej, literatury, prowadzono kursy księgowości, korespondencji handlowej, stenografii,

12 A. Tułodziecka, Praca społeczna kobiet w Poznaniu - referat czytany na zjeździe kobiet polskich w Krakowie 11 i 12 maja 1913 r., Biblioteka Raczyńskich, Akta Towarzystwa "Warta”. Papiery Anieli Tułodzieckiej i Janiny Omańkowskiej, s. 3-4.

13 Tamże, s. 6-7.

14 Tamże, s. 10.

15 A. Tułodziecka, dz. cyt., s. 13; Stowarzyszenie Personatu Żeńskiego w handlu i przemyśle w Poznaniu 1903-1913, Poznań 1913, s. 10-11. 
pomnażając tym samym szanse na lepszą pracę dla bardziej uzdolnionych. W końcu panie założyły spółkę Pracownia Sukien, w której były zarówno krawcowymi, jak akcjonariuszkami ${ }^{16}$. Kobiety uczyły się zasad współpracy i rozbudowywały swoją działalność, jednocześnie każda podejmowana przez nie praca prowadziła do wzmocnienia poczucia wspólnoty narodowej. Organizacje przyjmowały Polki i stwarzały kobietom szanse na rozwój poza strukturami niemieckich organizacji kobiecych, były wprawką przed pracą w wolnej Polsce i tak też były traktowane. Wszystkim działaczkom poznańskim zależało na zaangażowaniu jak największej liczby kobiet, szczególnie poza obszarem Poznania, który odgrywał rolę centrum, lecz ważne ośrodki poza nim pozostawały często bez własnych inicjatyw, stąd też starano się jak największego wsparcia udzielać na prowincji.

W oddalonych od stolicy zaboru pruskiego miejscowościach największe szanse rozwoju miały organizacje charytatywne. Prace zainicjowane przez poznańskie Towarzystwo Pań Miłosierdzia Św. Wincentego a Paulo kontynuowane były w wielu miejscowościach Wielkopolski, m.in. w Pobiedziskach. Tam dwukrotnie próbowano założyć Towarzystwo: po raz pierwszy w 1855 r., a drugi w $1916^{17}$. W Kobylnicy pod Poznaniem założono Towarzystwo Kolonii Wakacyjnych i Stacji Sanitarnych, które podlegało organizacji Stella Towarzystwo Kolonii Wakacyjnych i Stacji Sanitarnych w Poznaniu - tam mieścił się zarząd i stamtąd też pochodziły dzieci wysyłane na odpoczynek podczas wakacji, ale zorganizowanie Towarzystwa w małej miejscowości pozwoliło zaaktywizować również miejscową społeczność ${ }^{18}$. Stacja Sanitarna w Kobylnicy przyjmowała dzieci po przebytych chorobach, o słabej odporności lub niepełnosprawne, umożliwiając im $\mathrm{w}$ dobrych warunkach powrót do zdrowia albo podniesienie odporności. Dzieci chore nie były pozostawione bez żadnych zajęć, te, którym stan zdrowia na to pozwalał, uczyły się, dziewczynki zajęć domowych, a chłopcy m.in. stolarki ${ }^{19}$. Stała kolonia wakacyjna co roku zapewniała letni odpoczynek dzieciom. Podczas beztroskiej zabawy opiekunki zabierały dzieci na spacery oraz kąpiele $\mathrm{w}$ wierzenieckim jeziorze ${ }^{20}$.

W Gnieźnie w 1901 r. założono Towarzystwo Opieki nad Żłobkiem, które pomogło pracującym matkom rozstrzygnąć kwestię opieki nad dziećmi.

16 Stowarzyszenie Personału Żeńskiego w handlu i przemyśle, s. 10-11; A. Koehlerówna, dz. cyt.

17 Archiwum Archidiecezji Gnieźnieńskiej, Archiwum Parafii w Pobiedziskach, dokumenty Towarzystwa Pań Miłosierdzia św. Wincentego a Paulo, AAG/AP4376 .

${ }^{18}$ Korzystne relacje między środowiskiem miejskim Poznania a wiejskim Kobylnicy podkreślano także w sprawozdaniach z działalności instytucji, zob. "Stella" Towarzystwo Kolonii Wakacyjnych i Stacji Sanitarnych; Tow. zapisane w Poznaniu. XVIII. Sprawozdanie za rok 1913, Poznań 1914; S. Karwowski, dz. cyt., s. 240.

19 Sprawozdanie Towarzystwa Kolonii Wakacyjnych i Stacji Sanitarnej "Stella" w Poznaniu za rok 1902-1903, Poznań 1904, s. 19.

20 Tamże, s. 9-10. 
Inicjatywa rozwijała się nie bez przeszkód, okazała się jednak trwałym elementem życia społeczności nie tylko Gniezna, lecz i okolicznych miejscowości. Szczególne zasługi Towarzystwo miało podczas wojny, w latach 1914-1918, ponieważ kobiety, zmuszone do pracy w zastępstwie mężczyzn, prawie cały swój czas spędzały poza domem, a wówczas dzieci przebywały w żłobku pod opieką wychowawczyń ${ }^{21}$.

Inicjatywy rozwijane przez kobiety cieszyły się poparciem arcybiskupa gnieźnieńsko-poznańskiego Edmunda Dalbora, to zaś umożliwiało szybkie rozszerzenie zakresu podejmowanych działań, wykraczając poza ramy instytucji charytatywnej. Już w 1917 r. arcypasterz zobowiązał proboszczów parafii w całej archidiecezji do wyłonienia spośród parafianek tych pań, które chciałyby zgłosić się na kurs pielęgniarski organizowany przez poznańskie Towarzystwo Higieniczne. Zachęcano do uczestnictwa w kursie kobiety w wieku od 21. do 35. roku życia (potem od 40.), o doskonałym zdrowiu i zdolnościach finansowych, pozwalających na utrzymanie się podczas szkolenia w Poznaniu ${ }^{22}$. Projekt ten, realizowany podczas wojny, miał swoje wcześniejsze wersje, propagowane w nieco skromniejszym rozmiarze. Kursy urządzone w 1911 i 1913 r. trwały zaledwie dwa tygodnie, a planowane w 1917 r. początkowo obliczone były na trzy miesiące, później zaś przedłużone do sześciu. Dziewczęta pobierały nauki teoretyczne w sali wykładowej Wydziału Lekarskiego Poznańskiego Towarzystwa Przyjaciół Nauk, natomiast praktyczne w szpitalach poznańskich ${ }^{23}$. Z inicjatywy Towarzystwa Higienicznego organizowano „Samarytanki”, czyli grupy zajmujące się opieką nad chorymi ${ }^{24}$.

W Poznaniu funkcjonowało także Towarzystwo Katolickiej Opieki Dworcowej, które było częścią międzynarodowej organizacji Opieki Dworcowej, z centralą w szwajcarskim Fryburgu ${ }^{25}$. Podstawą działania tego Towarzystwa było zaangażowanie jak największej liczby osób gotowych pomagać również osobom przyjeżdżającym i wyjeżdżającym ze wsi i małych miejscowości. Głównym zadaniem, zgodnie ze statutem było „,[...] zwalczanie handlu dziewczętami i usuwanie niebezpieczeństw grożących kobietom i dziewczętom podróżującym przez udzielenie im odpowiedniej opieki i pomo-

${ }^{21}$ Archiwum Archidiecezji Gnieźnieńskiej, Archiwum Parafii Gniezno - Św. Trójcy, dokumenty Sprawozdanie z działalności Towarzystwa Opieki nad Żłobkiem (1901-1922), sygn. 59572.

${ }^{22}$ Archiwum Archidiecezji Gnieźnieńskiej, Archiwum Parafii Pobiedziska, dokumenty Towarzystwa Pań Miłosierdzia św. Wincentego a Paulo: Okólnik wydany w Poznaniu w dn. 8 listopada 1917 r., przez Arcybiskupa Gnieźnieńsko-Poznańskiego Edmunda Dalbora do wszystkich księży proboszczów; List Towarzystwa Hygienicznego w Poznaniu do księdza proboszcza w Pobiedziskach z dn. 4 stycznia 1918 r. sygn. AAG/AP4376.

${ }^{23}$ A. Tułodziecka, dz. cyt., s. 18.

24 Tamże, s. 19.

25 S. Karwowski, dz. cyt., s. 242. 
cy [...]"26. Istotne było objęcie działaniem Towarzystwa jak największej grupy osób, także na dworcach poza Poznaniem. Stąd list do proboszcza parafii farnej w Gnieźnie, zawierający prośbę o przyłączenie się księdza proboszcza do Towarzystwa i pełnienie funkcji opiekuna. W poznańskim oddziale pracowało w 1913 r. dziewięć kobiet i dwóch księży, pełnili oni dyżury na dworcu, na początku każdego kwartału, a także w okresie wiosennym, kiedy najwięcej osób przyjeżdżało w poszukiwaniu pracy. Zadaniem organizacji było zapewnienie opieki szczególnie młodym osobom, które bywały nierzadko ofiarami przestępców. Aby uchronić je od takiego losu, udzielano schronienia, porady dotyczącej wolnych stanowisk i biur pośrednictwa, które w sposób zgodny z prawem zajmowały się poszukiwaniem pracy ${ }^{27}$.

Pomoc kobietom oszukanym, ale i tym obawiającym się korzystania z biur stręczeń, zapewniało Stowarzyszenie Bezpłatnego Wykazu Pracy, które świadczyło pomoc młodym dziewczętom. Po opuszczeniu szkolnych ław często poszukiwały pracy samodzielnie, co nie zawsze kończyło się dla nich szczęśliwie. W trudnej sytuacji znajdowały się również młode kobiety pozbawione wykształcenia zawodowego, tak więc organizowano kursy umożliwiające zdobycie zawodu, następnie zaś starano się pomóc w przyjęciu podopiecznych do konkretnych, sprawdzonych miejsc pracy. Osobnym elementem działania była opieka nad kobietami trudniącymi się prostytucją, które chciały uczciwie pracować. I tutaj starano się sprostać oczekiwaniom zarówno samych zainteresowanych, jak i społeczeństwa, rzadko odnoszącego się pozytywnie do przemian ${ }^{28}$.

Zmieniające się zasady funkcjonowania kobiet $\mathrm{w}$ przestrzeni życia społecznego, szczególnie coraz częstsza obecność na rynku pracy, wymagała od nich korekt organizacyjnych. Stopniowo zmieniał się obraz kobiety pracującej jako tej, która nie potrafiła zaakceptować swego naznaczonego przez Boga i naturę miejsca u boku męża. Wraz z industrializacją i rozwojem gospodarki wolnorynkowej, na fali emancypacji niechcianej przez Polki z zaboru pruskiego, nadeszły zmiany. Wymogły one na kobietach walkę o zapewnienie sobie miejsca pośród osób trudniących się pracą zarobkową. Rzeczniczki każdego $\mathrm{z}$ zawodów reprezentowanych przez kobiety starały się organizować $\mathrm{w}$ towarzystwa, odgrywać rolę przedstawicielską. Pojawiło się zatem w 1907 r. Towarzystwo Opieki Katolickiej nad Służbą Żeńską. Jego głównym zadaniem było zapobieganie wyzyskowi ze strony biur pośrednictwa, na co najlepszym rozwiązaniem było założenie własnego biura stręczeń, a schronisko utworzo-

${ }^{26}$ Ustawy Towarzystwa Katolickiej Opieki Dworcowej w Poznaniu, Poznań [1899?], s. 1.

27 A. Tułodziecka, dz. cyt., s. 19; Archiwum Archidiecezji Gnieźnieńskiej, Archiwum Parafii Gniezno - Św. Trójcy, Akta dotyczące Towarzystwa Opieki nad Żłobkiem, (1910-1925): List przedstawicieli Katolickiej Opieki Dworcowej w Poznaniu do proboszcza parafii Farnej z kwietnia 1912, sygn. AP 59570 i AP59571.

28 A. Tułodziecka, dz. cyt., s. 17. 
ne przy organizacji zapewniało nocleg kobietom, które nie posiadały miejsca pobytu. Zajmowano się nie tylko wykwalifikowaną służbą, lecz i młodymi dziewczętami, które rozpoczynały starania o pracę i potrzebowały nauki, organizacja dawała również szansę rozwoju intelektualnego, organizowano pogadanki, wycieczki, założono bibliotekę. Wkrótce rozszerzyło działalność, zajmując się także wydawaniem obiadów i opiekując młodzieżą. Jak wspominała Aniela Tułodziecka, z niewiadomych przyczyn administracja niemiecka uznała je za organizację polityczną i zmierzała do jego zamknięcia ${ }^{29}$.

Związek Katolickich Stowarzyszeń Kobiet Pracujących, założony w 1906 r., gwarantował zrzeszonym w nim członkiniom opiekę prawną, możliwość podnoszenia kwalifikacji, a także umożliwiał wymianę doświadczeń między poszczególnymi organizacjami kobiet pracujących. Kobiety szybko zrozumiały, że pracując osobno, osiągną znacznie mniejsze efekty, niż działając wspólnie, jednakże nawet świadomość konieczności współdziałania nie ustrzegła pań od wzajemnych pretensji i niesnasek, a co za tym idzie - od popełniania błędów. Trudno było osiągnać porozumienie, znaleźć jedną kandydatkę na przewodniczącą, wypracować jedno rozwiązanie wszystkich trudności. Ograniczono liczbę stowarzyszeń, które przystąpiły do Związku. Z czasem uregulowano zasady funkcjonowania, a kobieca organizacja działała równie sprawnie jak męskie towarzystwa. W miarę upływu czasu wzrastała także liczba towarzystw, do których przyjmowano kobiety. Warto wspomnieć o Towarzystwie Gimnastycznym Sokól, w poczet którego były przyjmowane także dziewczęta (do 1908 r. nie mogły założyć odrębnej organizacji). Pierwsze gniazdo „Sokoła” zostało założone w 1867 r. we Lwowie, w latach osiemdziesiątych powstała organizacja poznańska. Jej członkowie, obok pracy nad rozwojem kultury fizycznej, prowadzili również prace społeczne. W jednym z tekstów umieszczonych w jubileuszowej publikacji „Sokoła” autorka pisze o kobietach: „[...] Czasy się zmieniły. [...] Dzisiaj słowem umiałyby sprostać publicznej myśli wymianie - zaznaczyć, iż obowiązek ten [wobec ojczyzny - P.K.] pełnią nie bezwiednie, lecz w poczuciu równych z mężczyznami obowiązków obywatelskich - że pełnią go nie "prawie bezwiednie «, lecz z całą świadomością swojej równej społecznej odpowiedzialności [...]"30. Ich dążenia do wyodrębnienia się spod kurateli mężczyzn spotykały się nie tylko z niekorzystną reakcją, lecz także ze zrozumieniem i pomocą. Gnieźnieński oddział żeński „Sokoła” powstał z udziałem mężczyzn, którzy służyli radą zarówno w opracowaniu statutu, jak i w codziennych zmaganiach z administracją niemiecką ${ }^{31}$. Ustawy Towarzystwa Dziennikarzy i Literatów Polskich

\footnotetext{
29 Tamże, s. 16-17.

${ }^{30}$ H. Rzepecka, Sokoli w Poznaniu w roku 1868, w: Srebrna Księga Sokoła Poznańskiego, Poznań 1911, s. 151.

${ }^{31}$ Z. Sachowa, Krótki zarys historii gniazda żeńskiego w Gnieźnie, w: Jubileuszowa Ksiaż̇a Pamiątkowa z okazji 50-lecia Gniazda Gnieźnieńskiego, Gniezno 1937, s. 60.
} 
na Rzeszę Niemiecką z 1905 r. dopuszczały, jeszcze przed ustawą z 1908 r., udział kobiet $\mathrm{w}$ jego szeregach. W Towarzystwie i pośród członków rzeczywistych, i honorowych mogły znajdować się kobiety, miały one w myśl statutu równe prawa z mężczyznami ${ }^{32}$.

Przełom w funkcjonowaniu kobiet w przestrzeni społecznej przyniosła wojna rozpoczęta w $1914 \mathrm{r}$. Wówczas matki i żony zajęły miejsce mężczyzn we wszystkich niemal dziedzinach funkcjonowania. Wtedy też zaaktywizowały się te Wielkopolanki, które dotychczas z różnych przyczyn nie angażowały się w życie społeczne. Wojna wymogła zmiany, przyspieszyła je i mimo trudności zmusiła do wzmożonej działalności istniejące już od pewnego czasu towarzystwa. Stowarzyszenie Personału Żeńskiego w Handlu i Przemyśle zintensyfikowało szkolenia dla kobiet, wskazując im konieczność podejmowania pracy i zrzeszania się w towarzystwa. Prowadzono kursy zawodowe, niższego i wyższego stopnia, organizowano wykłady z języka polskiego, historii, lecz i dotyczące nowego miejsca kobiety w społeczeństwie, jej zadań wobec rodziny ${ }^{33}$.

Ogromny wysiłek podjęły wszystkie organizacje charytatywne, starając się zapewnić bezpieczeństwo dzieciom, żywność i odzież walczącym, pomoc rodzinom żołnierzy, a potem powstańców, pozostawionym często bez środków do życia. Wszystkie dotąd istniejące towarzystwa jednoczyły się we współpracy. Towarzystwo Higieniczne powołało specjalistyczne kursy pielęgniarskie, podobnie uczyniły założycielki Oddziału Poznańskiego Polskiego Towarzystwa Czerwonego Krzyża. Polkom zależało szczególnie na tym, aby opieka nad rannymi przeszła w ich ręce. Tymczasem na początku 1919 r. Polski Urząd Sanitarny przejął placówki zdrowia, ale personel pozostał niemiecki. Kobiety zatem podjęły ogromny wysiłek i niemałe wyzwanie, próbując przeszkolić wszystkie dziewczęta, które zgłaszały się do pracy pielęgniarskiej ${ }^{34}$. Towarzystwo Opieki nad Żłobkiem zwiększyło liczbę dzieci przyjmowanych pod opiekę. Panie z Towarzystwa Pań Miłosierdzia św. Wincentego a Paulo starały się zapewnić sycący posiłek, a także zadbać o ciepłą odzież i bieliznę dla żołnierzy przebywających na froncie. Także w XIX w. kobiety niosły pomoc podczas powstań narodowych, więc ich działania podczas wojny światowej i powstania wielkopolskiego mieściły się w pewnych, wypracowanych wcześniej regułach, pozostawały także w utrwalonych kulturowo kanonach. Warto zaznaczyć, że było tak jedynie pozornie, obok działalności charytatyw-

32 Ustawy Towarzystwa dziennikarzy i literatów polskich na Rzeszę Niemiecka z siedzibą w Poznaniu, Poznań 1905, s. 3.

33 Biblioteka Poznańskiego Towarzystwa Przyjaciół Nauk, rkps. 888, Sprawozdanie z czynności Stowarzyszenia Personału Żeńskiego w Handlu i Przemyśle za rok 1916/1917. 15 rok istnienia.

34 Sprawozdanie z rocznej dziatalności Okręgu Wielkopolskiego Polskiego Towarzystwa Czerwonego Krzyża, wygłosz[one] na walnym zgromadzeniu delegatów w Poznaniu dnia 13 kwietnia 1920 roku przez Juliettę Przyjemska, sekretarkę w zarzadzie okręgowym, Poznań 1920, s. 2. 
nej bowiem, opieki nad rannymi i pracy codziennej, po raz pierwszy oficjalnie kobiety stanęły na froncie razem z mężczyznami. Liczna grupa pełniła służbę w oddziałach pomocniczych, wsparcia. Do najodważniejszych dziewcząt należały pielęgniarki, harcerki, członkinie "Sokoła”, zahartowane gimnastyką, posiadające wiedzę przekazaną im podczas zajęć teoretycznych. Przyzwyczajone do pracy fizycznej stanowiły nową siłę, której nie lekceważono. Z całą mocą podkreślano zatem rolę organizacji harcerskich, skautingowych i sokolich, tak bardzo zwalczanych przez administrację niemiecką, słusznie dostrzegającą $w$ nich przyszłe zagrożenie ${ }^{35}$. Zakończenie I wojny światowej przyniosło upragnioną niepodległość Polski, a także niespodziewane dla sytuacji kobiet rozwiązanie prawne: otrzymały czynne i bierne prawo wyborcze. Trudno było o większe podkreślenie ich zasług, a także zwienczenie działań prowadzonych w przestrzeni społecznej od niemal stulecia.

Był to nie tylko akt polityczny. Bez wątpienia Rzeczpospolita, przyznając Polkom miejsce w szeregu współdecydujących o jej losach, podniosła znaczenie kobiet, doceniła ich wysiłek, lecz nie u każdej obywatelki przyznane prawo wywołało zadowolenie i dumę bądź satysfakcję. W przeciwieństwie do państw europejskich, gdzie walka o prawa wyborcze była konsekwentnie prowadzona przez cały wiek XIX, a wcale nie doprowadziła do przełomu w prawodawstwie, Polki, właściwie nie zabiegając o prawa wyborcze nawet $\mathrm{w}$ połowie tak energicznie jak inne Europejki, otrzymały je. Zasługi Polek dla ocalenia tożsamości narodowej, odbudowy niepodległego państwa były dla każdego mężczyzny czymś, co powodowało, że nie wyobrażano sobie postąpić inaczej ${ }^{36}$. Można zatem stwierdzić, że trudne dla narodu chwile przyniosły ewolucję $\mathrm{w}$ postrzeganiu roli i miejsca kobiet $\mathrm{w}$ społeczeństwie, narodzie i państwie. W tym jednak miejscu zaznaczyć wypada, że ich pozycja nie była w całej odrodzonej Polsce taka sama. Przyczyn zróżnicowania w położeniu Polek należy upatrywać w kilku płaszczyznach. Po pierwsze, niepodległość odzyskana 11 listopada 1918 r. nie dotyczyła Warmii, Mazur, Śląska ani Wielkopolski. Podczas gdy na ziemiach II Rzeczypospolitej kobiety włączyły się w życie państwa, biorąc udział w pierwszych wyborach w 1919 r., panie mieszkające na Śląsku, Mazurach, na Warmii, a także te z Wielkopolski brały udział w decydującym o ich przyszłości stadium walki.

Dopiero rok 1922 rozstrzygnął ostatecznie o kształcie ziem Polski. Już $\mathrm{w}$ pierwszych miesiącach niepodległości wiedziano, że scalenie terenów przyznanych Polsce nie będzie ani łatwym zadaniem, ani tym bardziej prędko przebiegającym, ponad stuletnia przynależność do trzech różnych państw,

$35 \mathrm{O}$ udziale kobiet $\mathrm{w}$ walkach podczas powstania wielkopolskiego i działaniu drużyn harcerskich zob.: J. Karwat, Od idei do czynu. Myśl i organizacje niepodległościowe w Poznańskiem w latach 1887-1919, Poznań 2002, s. 443; A. Barłóg, Udział kobiet w powstaniu wielkopolskim 1918-1919, Poznań 2008.

${ }^{36}$ M. Pietrzak, dz. cyt., s. 28. 
inaczej zarządzanych, kierujących się innymi wyznacznikami, prowadzących własną politykę wobec okupowanych narodów, musiało wpłynąć na zamieszkujących je Polaków. Jeszcze podczas wojny światowej pojawiły się różnice między obozami politycznymi optującymi na rzecz niepodległości Polski. I tak jak zróżnicowane były poglądy na jej kształt pośród mężczyzn, tak też różne były przekonania Polek, nie tylko na kształt państwa, lecz nade wszystko na rolę $\mathrm{w}$ nim kobiety.

Wielkopolanie czynem zbrojnym przypieczętowali swoją przynależność do Rzeczypospolitej, Polki w trudnych chwilach walki ani na chwilę ich nie opuściły. Uzyskanie wolnej ojczyzny stanowiło dla Wielkopolanek wyzwanie, albowiem dotąd wszystkie podejmowane przez nie wysiłki skoncentrowane były na zachowaniu narodowości, wiary i języka polskiego. W nowej rzeczywistości te, które obawiały się emancypacji, nie tylko musiały się z nią zmierzyć, ale też odnaleźć swoje miejsce w przestrzeni społecznej. Początki nie były łatwe. Kobiety najbezpieczniej czuły się prowadząc, działalność charytatywną. Pozostawała ona w obrębie przypisanych im kulturowo cech i powinności. Stąd też prężny rozwój nowych oddziałów czy kół takich organizacji, jak: Towarzystwo Pań Miłosierdzia św. Wincentego à Paulo, Kuchnia dla Ubogich, Katolicki Związek Polek. Nadal działało Towarzystwo Kolonii Wakacyjnych i Stacji Sanitarnych Stella. Także wysiłki stowarzyszeń zrzeszających kobiety pracujące nie ustały, jeszcze w 1918 r., w Janowcu Wielkopolskim założono Towarzystwo Kobiet Pracujących, które pozostając w łączności z centralą poznańską, aktywizowało lokalne środowisko robotnic, nie pozwalało im również po odzyskaniu niepodległości zaprzestać pracy nad podnoszeniem kwalifikacji ${ }^{37}$.

W przywoływanym już sprawozdaniu z działalności Polskiego Towarzystwa Czerwonego Krzyża odnaleźć można jednak uwagi krytyczne, adresowane do Wielkopolanek, które gdy poczuły się bezpiecznie w niepodległym państwie, szybko porzuciły dotychczasową pracę na rzecz narodu, skupiając się jedynie na pracy zawodowej i życiu rodzinnym, poprzestając na obowiązkach dnia codziennego ${ }^{38}$. Wiele czołowych działaczek życia narodowego pod zaborem pruskim działało nadal, pracując nad aktywizacją Polek. Pośród nich znajdowała się Zofia Rzepecka, która jako członkini Związku Katolickiego Polek była obecna podczas obrad stowarzyszenia, ona również wskazywała na słabnącą aktywność kobiet. W Związku nie wzrastała liczba stowarzyszeń ani pracujących na jego rzecz pań. Podczas obrad poruszano więc kwestie związane z potrzebą uświadomienia Polek w kwestii powinności względem społeczeństwa. Poświęcono także wiele uwagi prawom

37 Archiwum Archidiecezji Gnieźnieńskiej, Archiwum Parafii Janowiec, dokumenty Towarzystwa Kobiet Pracujacych, sygn. AP6788.

38 Sprawozdanie z rocznej działalności Okręgu Wielkopolskiego Polskiego Towarzystwa Czerwonego Krzyża, dz. cyt., s. 2. 
politycznym kobiet i ciążącej na nich odpowiedzialności za kształt rządów w państwie ${ }^{39}$.

Kobiety bardzo szybko włączyły się do pracy narodowej, zarówno jawne, jak i tajne towarzystwa służące zachowaniu polskości świadczyły o świadomości narodowej Polek i o poczuciu tożsamości, której nie zdołało osłabić żadne z postanowień pruskich, a potem niemieckich decydentów. Koniec wieku XIX, zmiany w społeczeństwach fin de siècle'u zmusiły polskie damy, dotychczas podporządkowane mężczyznom, do samodzielnej egzystencji. Wówczas zrozumiały, że wymiana wspólnych doświadczeń oraz budowanie jednego stanowiska $\mathrm{w}$ sprawach, które dotyczyły wszystkich kobiet, mogą im pomóc w zdominowanym przez mężczyzn świecie. Działając w obronie interesów narodowych i własnych, nauczyły się wpływać na losy narodu. Doświadczenia zdobyte $\mathrm{w}$ towarzystwach zakładanych przez cały wiek XIX miały im ułatwić funkcjonowanie w niepodległym państwie. Tymczasem wydawać by się mogło, że przeciwnie, utrudniły im działania, spowodowały, że po początkowym rozwoju i okresie "przebudzenia" nastąpiło spowolnienie, a nawet uśpienie działalności organizacji kobiecych ${ }^{40}$.

Prawa polityczne były dla Polek jak brzemię, a czyż nie stanowiły efektu kobiecej agitacji przedwyborczej, która odbywała się na terenach całego zaboru pruskiego, gdzie matki, żony i siostry nakłaniały mężczyzn do głosowania na polskich kandydatów? Jeszcze w XIX w. redaktorzy polskich gazet zwracali się do kobiet: „Obywatelki Polki! Wysyłajcie swych mężów na wybory, od rezultatu bowiem takowych zależeć może będzie wychowanie waszych dziatek $\mathrm{w}$ wierze katolicko-polskiej, tego wymaga nasz honor narodowy, wreszcie rozliczne sprawy miejskie" ${ }^{41}$. Udział kobiet w wyborach parlamentarnych w $1922 \mathrm{r}$. nie przez wszystkie zainteresowane był rozumiany w taki sam sposób. Inaczej pojmowały wolność polityczną kobiety z dawnej Galicji, cieszącej się szeroką autonomią, która pozwoliła na rozwój ruchów kobiecych, a to z kolei doprowadziło do wykształcenia się świadomych również swoich obywatelskich powinności Polek. Inaczej rozumiały życie polityczne mieszkanki Kongresówki. Pod zaborem rosyjskim niszczono wszelkie przejawy polskości, a kobiety na przekór władzom współdziałały z Galicją i starały się na równi z mężczyznami o zwiększenie praw Polaków. Tam też silny wpływ partii socjalistycznych przyspieszył emancypację kobiet. Najmniej w życie polityczne angażowały się kobiety z ziem dawnego zaboru pruskiego. Dla większości z nich walka o przetrwanie, o rozwój i utrzymanie świadomości narodowej oraz próba zachowania najmniejszych nawet ustępstw ze strony rządu

${ }^{39}$ Katolicki Zw. Polek (sprawozdanie pani Rzepeckiej), „Kurier Poznański” (dalej: KP), nr 210 z 14 września 1922 r.

${ }^{40}$ K. Sierakowska, Samoorganizowanie się kobiet w II Rzeczypospolitej: dążenia, szanse, realizacje, w: Działaczki społeczne, s. 36.

${ }^{41} \mathrm{KP}, \mathrm{nr} 273$ z 26 listopada $1884 \mathrm{r}$. 
niemieckiego przesłaniały wszystkie inne dążenia, pogardliwie często nazywane emancypacją.

Nie oznacza to, że działaczki tamtejsze nie rozumiały doniosłości zmian. Prowadziły agitację pośród kobiet, uświadamiając im, że korzystanie z praw obywatelskich jest obowiązkiem każdej Polki. Jeszcze przed oficjalną decyzją, wydaną przez Naczelnika państwa Józefa Piłsudskiego, poparcia dla nowych rozwiązań zrównujących prawa kobiet i mężczyzn szukano pośród duchownych. Patron Związku Katolickich Stowarzyszeń Kobiet Pracujących skierował poufny okólnik do wszystkich księży patronów, jednoznacznie opowiadając się za przyznaniem praw wyborczych kobietom i zalecając jednocześnie podobne stanowisko pozostałym. Podkreślił w liście dojrzałą, obywatelską postawę kobiet, predyspozycje wychowawcze, które miały dobrze wpływać na rozstrzyganie trudnych kwestii politycznych, a także przychylność dla spraw Kościoła katolickiego ${ }^{42}$.

Istotnym elementem pracy nad uświadomieniem politycznym Wielkopolanek było odwoływanie się do duszy narodowej, nazywanie Polek „nowożytnym rycerstwem polskim" i zwracanie się do nich w sposób następujący: „[... [ Kobiety dotrwajcie na posterunku w służbie dla Chrystusa i Ojczyzny!/ Kobiety do broni! Jest nią wasz głos wyborczy, wasz wpływ na ojców, braci, mężów, synów, narzeczonych, na współpracowników, na kobiety mniej uświadomione $[\ldots]^{\prime \prime 3}$, „,...] A więc przyszłość Ojczyzny spoczywa w rękach kobiet; zależy od ich politycznego uświadomienia i od wypełnienia obowiązków obywatelskich przez kobiety"44. Częściej niż wzniosłe słowa można odnaleźć uwagi krytyczne. Nie były one kierowane tylko do kobiet, lecz i do mężczyzn. Wszystkie wiązały się z nakłanianiem Polek do zajmowania się sprawami leżącymi w sferze życia rodzinnego i poprzestania na nich właśnie. Umożliwiłoby to mężczyznom odzyskanie całkowitego wpływu na życie polityczne państwa. Istotnie, wiele pań rezygnowało bądź zamierzało zrezygnować z przyznanych im praw. Te, które zajęły się niewdzięczną pracą polegającą na uświadamianiu politycznym koleżanek, szybko orientowały się, że podjęte przez nie działania muszą być kierowane tak do samych zainteresowanych, jak i do ich mężów. Nierzadkie były przypadki, kiedy na zebraniach politycznych, wiecach organizowanych dla kobiet zarówno w miastach, jak i na wsiach, pojawiali się tylko mężczyźni albo kilka kobiet ${ }^{45}$. Matki i żony tłu-

${ }^{42}$ Archiwum Archidiecezji Gnieźnieńskiej, Archiwum Parafii Pobiedziska, dokumenty Towarzystwa Pań Miłosierdzia św. Wincentego a Paulo: List Związku Stowarzyszeń Katolickich Kobiet Pracujących przesłany do Patrona Związku 9 listopada 1918 r., sygn. 4376.

43 Apel do kobiet!, KP, nr 259 z 11 listopada 1922 r.

44 Udziat kobiety w polityce, "Głos Wielkopolanek. Tygodnik społeczno-narodowy dla kobiet wszystkich stanów", nr 44 z 29 października 1922 r.

${ }^{45}$ Udziat kobiety w polityce, dz. cyt.; Migawki przedwyborcze III, „Dziennik Poznański” (dalej: DzP), nr 245 z 26 października 1922 r. 
maczyły się brakiem czasu, a nawet niezrozumieniem zagadnień związanych z polityką, panowie wtórowali im, przedstawiając znane jeszcze z poprzedniego stulecia obawy dotyczące rozpadu rodziny z powodu zaangażowania kobiet w życie publiczne, upadek obyczajów etc. Niektórzy zaś wskazywali na całe stulecia, w których państwa istniały i rozwijały się bez udziału kobiet w życiu publicznym ${ }^{46}$. Wiele spośród tych pań, które słyszały podczas wieców, że głosowanie jest ich obowiązkiem, postanawiało oddać głos na tego samego kandydata, którego popierał mąż, nie dlatego, że nie miały własnych poglądów, lecz w imię spokoju i zgody w małżeństwie ${ }^{47}$.

Walka o głosy kobiet toczyła się na dwóch frontach. Pierwszym było uświadomienie kobietom obowiązku udziału w życiu publicznym również poprzez czynne uczestnictwo w wyborach, bez zaznaczania, na którą partię polityczną powinny głosować. Drugi front tworzyli politycy należący do określonych stronnictw, którym nie tyle zależało na świadomym obywatelskim życiu politycznym z udziałem kobiet, ile na jak największej liczbie głosów ${ }^{48}$. I tak, chrześcijańscy demokraci odwoływali się do obowiązku kobiety - katoliczki, patriotki, która miała w swoich rękach losy narodu; partie socjalistyczne kierowały swoją uwage do środowisk robotniczych, wiejskich i emancypantek, podkreślając wielowiekowy ucisk kobiet, jarzmo klas posiadających, które poprzez udział w głosowaniu miały szansę zrzucić ${ }^{49}$. Zaangażowanych w agitację było zatem wielu. Nie wszędzie niska frekwencja pośród obywatelek z Wielkopolski rzucała cień na ogólny obraz ich aktywności politycznej. Wiec wyborczy w Miłosławiu zgromadził ponad trzysta pań. Również we Wrześni i Krobi pojawiło się wiele zainteresowanych prawem wyborczym i możliwościami, które ono stwarzało dla kobiet ${ }^{50}$.

Możliwość poznania praw przysługujących kobietom dawały nie tylko wiece i prelekcje poszczególnych reprezentantek partii politycznych, lecz także broszury zawierające dokładne informacje zarówno na temat wynikających z przyznanych praw obowiązków dla kobiet, jak również szans na rozwój własnych aspiracji politycznych. Autorką jednej z nich była żona pierwszego prezydenta Poznania Jarogniewa Drwęskiego, Izabela. Kobieta wywodząca się z rodziny ziemiańskiej, akceptowała ducha nowych czasów, co budziło zastrzeżenia jej konserwatywnej matki Anny z Grossmanów Amrogowiczowej. Obiekcje matki nie powstrzymały Izabeli przed zdaniem matury i wyjazdem

46 Udziat kobiety w polityce.

${ }^{47}$ Migawki przedwyborcze, DzP, nr 238 z 18 października 1922 r.

48 A. Żarnowska, Obywatelki II Rzeczypospolitej, w: Kobiety w Polsce międzywojennej, s. 288.

${ }^{49}$ Migawki przedwyborcze I, II, III, IV, DzP, nr 238 z 18 października 1922 r., nr 240 z 20 października 1922 r., nr 245 z 26 października 1922 r., nr 246 z 27 października 1922 r.; KP, nr 252, z 3 listopada 1922 r., nr 257 z 9 listopada 1922 r.

${ }^{50} \mathrm{KP}$, nr 233 z 13 października 1922 r. nr 238 z 17 października 1922 r., nr 253 z 4 listopada $1922 \mathrm{r}$. 
do Szwajcarii w celu pobierania dalszej nauki ${ }^{51}$. Małżeństwo z młodym, obiecującym prawnikiem Jarogniewem Drwęskim pomogło kobiecie realizować się także w życiu osobistym. Prezydentura Jarogniewa nałożyła na nią wiele nowych obowiązków, którym podołała, lecz prawdziwym wyzwaniem było utrzymanie rodziny po przedwczesnej śmierci męża. Wówczas właśnie rozpoczęła pracę zarobkową, wtedy też napisała broszurę Dlaczego głosowanie jest obowiazkiem sumienia każdej kobiety? ${ }^{52}$. Jako doświadczona Polka, wychowana w patriotycznej rodzinie, współorganizatorka pomocy podczas wojny światowej i powstania wielkopolskiego, czuła obowiązek uświadomienia wszystkich tych kobiet, które wątpiły w sens otrzymanych praw. Napisana przez nią praca została zakupiona przez Komitet Wyborczy i była również rodzajem agitacji kobiet ${ }^{53}$. Autorka wyjaśniała w przystępny sposób, czym są sejm, senat, jaka jest rola konstytucji, a także na czym polegają prawa kobiety. Ona też wskazała kobietom ich kompetencje matek, wychowawczyń, prowadzących gospodarstwa domowe ${ }^{54}$. One wiedziały o codziennym funkcjonowaniu rodzin więcej niż jakikolwiek mężczyzna, bo to na nich spoczywał obowiązek wychowania dzieci, pomocy w przyswojeniu materiału zadanego w szkołach, to one wiedziały, czy pensja męża wystarcza na podstawowe potrzeby gospodarstwa domowego, one też walczyły z drożyzną, wprowadzając w domach kolejne zasady oszczędności. Drwęska również odwołała się do tradycji kobiety strażniczki wiary, poruszając tematy związane ze ślubami cywilny$\mathrm{mi}$, rozwodami, sytuacją kobiet i dzieci w chwili rozpadu rodzin ${ }^{55}$.

Odrębną działalność na rzecz uświadomienia politycznego prowadziły panie zrzeszone w Narodowej Organizacji Kobiet (NOK) ${ }^{56}$. Warszawskie aktywistki bardzo dobrze wiedziały, że poziom wiedzy i działalności społecznej pośród Polek jest bardzo zróżnicowany, a pozostawanie w ramach organizacji politycznych prowadzonych przez mężczyzn zawsze będzie stawiało kobiety $\mathrm{w}$ drugim szeregu ${ }^{57}$. Chcąc tego uniknąć, zakładały oddziały na terytorium całej Rzeczypospolitej, jednocząc Polki w dążeniach do udziału w życiu publicznym, zachęcając również do zakładania własnych partii politycznych. Tak na początku, jak i po kilku latach działalności, organizacja nie

51 G. Łukomski, Jarogniew Drwęski (1875-1921). Biografia Wielkopolanina wybitnego na tle epoki, Warszawa-Poznań 2003, s. 169-171.

${ }^{52}$ I. Drwęska, Dlaczego głosowanie jest obowiazkiem sumienia każdej kobiety?, Poznań 1922.

${ }^{53}$ Wspomnienia Izabeli Drwęskiej dla wnuczki Ewy, zeszyt II, s. 10 [maszynopis w posiadaniu autorki].

${ }^{54}$ Tamże, s. 5-6.

55 Tamże, s. 7-8.

56 Organizacja ta została założona w Warszawie w 1919 r., przed pierwszymi wyborami, w których miały wziąć udział kobiety. Jej celem było omówienie zasad związanych z możliwością funkcjonowania Polek $\mathrm{w}$ świecie polityki, a także rozbudzenie $\mathrm{w}$ nich aspiracji politycznych. R. Kotowski, Między polityka, a działalnością społeczna - Narodowa Organizacja Kobiet w dwudziestoleciu międzywojennym, w: Działaczki społeczne, s. 276-277.

57 Statut Narodowej Organizacji Kobiet, Warszawa 1921, s. 1-2. 
zmieniła swoich celów, stawiając sobie jako naczelne posłannictwo włączenie kobiet w nurt życia politycznego Rzeczypospolitej Polskiej ${ }^{58}$. W Poznaniu NOK była m.in. organizatorką wieców przedwyborczych, warto zaznaczyć, że nie bezstronnych. Zrzeszone $\mathrm{w}$ jej strukturach kobiety popierały stronnictwo Narodowych Demokratów ${ }^{59}$. Posłanką z Poznania i działaczką na rzecz spraw kresów zachodnich Rzeczypospolitej była Zofia Sokolnicka, ceniona przez Narodową Organizację Kobiet, do której należała, za łączenie spraw istotnych dla kobiet z ideami narodowymi oraz interesami Wielkopolski ${ }^{60}$.

Funkcjonowanie Polek $w$ okresie przełomu XIX i XX stulecia $w$ ramach różnego rodzaju organizacji kobiecych było nierozerwalnie związane z ideą krzewienia wartości narodowych i katolickich, które utożsamiane były wówczas z polskimi. Wyjście spod kurateli mężczyzn spowodowało, że wiele kobiet rozpoczęło pracę zarobkową, aby zapewnić sobie byt. Poza nimi istniała wąska grupa ambitnych pań, chętnych do kontynuowania edukacji czy aktywnej pracy na forum publicznym. Pierwszym przejawem pojawienia się kobiet $\mathrm{w}$ sferze życia publicznego były jawne organizacje kobiece. One wskazywały charakter podejmowanych wyzwań i wyznaczały granice zainteresowań przestrzenią publiczną, nie było pośród nich polityki, kwestii równouprawnienia z mężczyznami itp. Drugim etapem wkraczania kobiet w przestrzeń społeczną było uczestnictwo $\mathrm{w}$ wiecach, zebraniach, zakładanie związków, towarzystw, bo aby móc się jednoczyć, kobiety musiały osiągnąć wysoki szczebel organizacji i posiąść umiejętności zarządzania, a nade wszystko przekonać sceptyków do słuszności podejmowanych działań, co nie zawsze było łatwe. W każdym działaniu towarzyszyła Polkom prasa, nie zawsze przychylna, czasem niesprawiedliwa i wyrażająca opinie konserwatywne, niechętne zmianom, kiedy indziej ośmieszająca ich wysiłki. Ostatecznie jednak podkreślano w prasie zasługi kobiet dla życia narodowego, zachęcano do dalszej pracy, relacjonowano kongresy kobiece, wiece w sprawach narodowych z udziałem pań.

$\mathrm{Na}$ łamach prasy lat dwudziestych i trzydziestych ubiegłego wieku odnaleźć możemy zachętę dla kobiet do zrzeszania się w organizacje, do pracy $\mathrm{w}$ towarzystwach do udziału w życiu politycznym. Możemy zatem powiedzieć, że trzecim etapem włączania kobiet do życia obywatelskiego, do pełnego funkcjonowania w życiu społecznym, było przyznanie im praw politycznych. Polki osiągnęły bardzo wiele, albowiem prawa wyborcze należy postrzegać jako wyraz docenienia ich pracy rozpoczętej $\mathrm{w}$ niezwykle trudnych warunkach ${ }^{61}$. Czy zatem powinniśmy z potępieniem spoglądać na spo-

58 Kobieta w Sejmie. Działalność postanek Narodowej Organizacji Kobiet. Zarys sprawozdania za lata 1919-1927, Warszawa 1928, s. 4-5.

${ }^{59} \mathrm{KP}, \mathrm{nr} 251 \mathrm{z} 1$ listopada 1922 r., nr 253 z 4 listopada 1922 r.

60 Kobieta w Sejmie, s. 8-10.

61 K. Sierakowska, dz. cyt., s. 33. 
wolnioną $\mathrm{w}$ okresie pierwszych lat niepodległości egzystencję $\mathrm{w}$ przestrzeni społecznej? W zakresie aktywności kobiet w okresie II Rzeczypospolitej zaszły zmiany. Pierwszą było osiągnięcie poczucia bezpieczeństwa, które spowodowało, że tajne organizacje samokształceniowe, czytelnie, biblioteki wydawały się organizacjami zbędnymi, choćby dlatego, że wysiłek wykształcenia $\mathrm{w}$ duchu polskim, spoczywający w czasach zaboru pruskiego głównie na kobietach, został przejęty przez państwo, przez szkoły, biblioteki publiczne, świetlice itp. Działalność chary tatywna natomiast nie tylko nie ustała, lecz uległa wzbogaceniu o nowe inicjatywy, rozkwitało życie towarzyskie, w wolnym państwie prowadzone swobodnie. Powstawały stowarzyszenia zawodowe przy zakładach pracy i przedsiębiorstwach, w każdym zaangażowane były także kobiety. Warto pamiętać również o tym, że coraz częściej panie były członkiniami towarzystw zakładanych przez mężczyzn. Niewątpliwie największe osiągnięcie, a więc prawa wyborcze, było także największym wyzwaniem, uniemożliwiało cichą pracę w swoim gronie, do której kobiety zdążyły się przyzwyczaić i wymagało niekiedy radykalnego forsowania argumentów, obok kwestii związanych z życiem rodzinnym, wymuszało poszerzenie horyzontów, w końcu praca w sejmowych ławach czy odpowiedzialność za los narodu wymagały od wyborczyń świadomości politycznej. Udział kobiet w przestrzeni społecznej II Rzeczypospolitej bez pracy rozpoczętej w XIX w. byłby niemożliwy. Uświadomienie, również społeczne i polityczne, jest bowiem procesem, w którym długa droga to nie tylko czas rozwoju kobiety - świadomej obywatelki, lecz i mężczyzny - gotowego, aby dzielić przestrzeń społeczną z kobietą.

Patrycja Kanafocka

\section{Wielkopolskie organizacje kobiece u schyłku XIX w. a uczestnictwo Polek w przestrzeni społecznej II Rzeczypospolitej Polskiej}

\footnotetext{
Streszczenie

W zakresie aktywności kobiet w okresie II Rzeczypospolitej zaszły zmiany. Pierwszą było osiągnięcie poczucia bezpieczeństwa, które spowodowało, że tajne organizacje samokształceniowe, czytelnie, biblioteki wydawały się zbędne, choćby dlatego, że wysiłek wykształcenia w duchu polskim spoczywający w czasach zaboru pruskiego głównie na kobietach, został przejęty przez państwo. Działalność charytatywna natomiast uległa wzbogaceniu o nowe inicjatywy, rozkwitało życie towarzyskie, w wolnym państwie prowadzone swobodnie. Powstawały stowarzyszenia zawodowe przy zakładach pracy i przedsiębiorstwach, w każdym zaangażowane były także kobiety. Przyjmowano je również do towarzystw zakładanych przez mężczyzn. Niewątpliwie największe osiągnięcie, a więc prawa wyborcze, było także wyzwaniem, uniemożliwiało cichą
} 
pracę w swoim gronie, do której kobiety zdążyły się przyzwyczaić i wymagało niekiedy radykalnego forsowania argumentów, wymuszało poszerzenie horyzontów. Udział kobiet w przestrzeni społecznej II Rzeczypospolitej bez pracy rozpoczętej w XIX wieku byłby niemożliwy. Uświadomienie bowiem, również społeczne czy polityczne, jest procesem, w którym długa droga to nie tylko czas rozwoju kobiety - świadomej obywatelki, lecz i mężczyzny, gotowego, aby dzielić przestrzeń społeczną z kobietą.

\title{
Women's organizations at the end of the 19th century and the participation of Polish women in the social life of the Second Polish Republic
}

\begin{abstract}
When it comes to the activity of women during the times of the Second Republic, there were a lot of changes. Firstly, a sense of security was gained, which meant that secret self-education, reading rooms and libraries were redundant, since the effort of educating in the Polish spirit during Prussian occupation, mostly made by women, was overtaken by the state. Charitable activity was enriched with new initiatives, and social life flourished, because it could be led freely in the free state. Professional associations at plants and companies emerged, in which women also participated. Women were also welcome in societies established by men. Undoubtedly, the biggest achievement, the right to vote, was also a challenge, as it made it impossible to work quietly in limited, female-only circles - an activity women had managed to get used to. This sometimes required radical argumentation, and forced one to stay open minded. Female participation in the public life of the Second Republic would have been impossible without the work that had began in the 19th century. Raising awareness, both social and political, is a process. Long way is required not only for a woman to become a conscious citizen, but also for a man to become ready to share the social space.
\end{abstract}

